\title{
OJO DE MEDUSA
}

Susana Patiño*

${ }^{66} \mathrm{E}_{\text {stamos subiendo en un elevador }}$ de alta velocidad. En menos de un minuto llegaremos al piso 62 de la torre más alta de América Latina: mide 300 metros, tan solo 10 menos que la Torre Eiffel. En el mirador tendrán una vista de 360 grados de Santiago y, accediendo al piso superior, respirarán el aire más puro de la ciudad a cielo abierto. Disfruten su visita."

Las puertas se abren para ponernos cara a cara con los gigantes: ahí está la misma nieve con la que jugábamos hace apenas unas horas pero ahora vista a lo lejos, coronando la cordillera y con un gigantesco manto de luces extendido a sus pies. El sol ya se fue pero todavía alcanzamos su último rastro en el horizonte. El impulso de pararme al borde del precipicio es irresistible: tan solo dos centímetros me separan del abismo. ¿Por qué no tengo miedo? ¿Dónde están las cosquillas en las manos? ¿Qué mecanismo se apagó en mi mente para que yo no sea consciente del lugar en el que estoy?

Un salto ligero borra mis preguntas, se siente como si hubiera pasado un camión pesado que mueve ligeramente el suelo. La segunda sacudida es más seria: hay que alejarnos de los vidrios. Algunos corren desesperados a la escalera. Yo sólo tengo un pensamiento: "hay que grabar".

* Escritora. 
Doy play y entonces comienza la danza más majestuosa que haré en mi vida. Veinte mil ciento cincuenta toneladas de acero comienzan a balancearse a un ritmo cadencioso. Es como bailar un vals de Shostakóvich pero sin violines. La música es cortesía del esqueleto del edificio: una orquesta fiel que seguirá tocando hasta el final, como la del Titanic. No es un ruido estridente, tampoco es caótico, es el sonido de las ondas en expansión. Dicen que así se escuchan las trompetas en el cielo. No puedo evitar pensar que vamos a caer en cualquier instante pero nuestro baile con el Costanera es suave y al parecer eterno.

Ya pasó un minuto y los vidrios no se han quebrado, deben estar blindados. La música sigue sonando, viene de arriba. Hay una gigantesca estructura metálica que amenaza a mi mente con venirse abajo, pero lo único que cae al piso es mi razón porque aquí no pasa nada. Nuestra pareja se rinde y al final nos deja libres. La mayoría huye por las escaleras, los más eufóricos se toman selfies celebrando que vencimos al gigante. La algarabía dura un suspiro, la réplica empieza de inmediato y entonces las instrucciones de los guardias pierden el tono amable para adquirir un destello militar:

"Van a evacuar el edificio bajando por las escaleras. Son 62 pisos, van a tardar aproximadamente media hora, si vuelve a temblar no se preocupen porque estarán en el lugar más seguro del edificio.”

O tal vez estamos en el lugar más seguro de todo Chile. El Costanera Center fue diseñado para resistir terremotos de 12 grados. Hay un péndulo gigante en su centro que se encarga de mantener el equilibrio. Por eso vencimos a la tiranía de la gravedad. El Costanera hacía su propio trabajo bailando embelesado una danza fractal consigo mismo.

La escalera de emergencia no la han limpiado nunca: los rastros de obra negra reciente están a cada paso y no riman con el glamour del centro comercial. En el piso 60 hay llamadas, fotos, gente texteando. En el 45 se escucha la siguiente réplica. Insisto, "se escucha" porque la consciencia del movimiento la perdimos hace muchos escalones; es el sonido de algo que parece una explosión en los cimientos del edificio el que se expande en todas direcciones. En el 30 nos detenemos a estirarnos porque un calambre sería fatídico. En el 20 los niños ya están 
demasiado cansados y asustados. En el 10 un hombre obeso y joven parece al borde de un paro cardíaco. En el 6 hay una escalera tirada descuidadamente bloqueando el paso, en el 3 notamos que faltan extintores, que las instalaciones eléctricas están pelonas y las luces de emergencia, desconectadas. ¿Estaremos realmente listos para inaugurar el Costanera en su totalidad? Pero después de 45 minutos bajando escaleras ya nada importa: salimos como héroes agigantados luego de nuestra danza entre la vida y la muerte.

Nosotros también estamos hechos para soportar terremotos de 12 grados y un péndulo interno nos sostiene, pero ojalá pudiéramos mirar con los ojos que ven las medusas: ellas salieron del mar dos días antes del tsunami, como si nos hicieran un favor alejándonos de la costa con sus neurotoxinas. Ojalá pudiéramos ver con otros ojos lo realmente importante. México, cuídate: la medusa está en la playa. 
CITAM Derechos Reservados.

La reproducción total o parcial de este artículo se podrá hacer si el ITAM otorga la autorización previamente por escrito. 